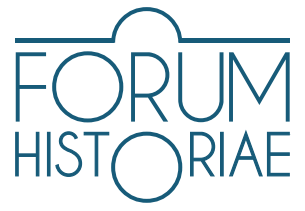

\title{
Italy's Great Power Strategies in Central-Eastern Europe Between the World Wars: Cultural Institutions and Poli- tical Propaganda
}

\author{
Stefano Santoro
}

\begin{abstract}
SANTORO, Stefano. Italy's Great Power Strategies in Central-Eastern Europe Between the World Wars: Cultural Institutions and Political Propaganda.

This article addresses the issue of Italian penetration in Central-Eastern Europe in the interwar period, paying particular attention to the case of Czechoslovakia and covering primarily the tools used by Italy to assert its influence among the "heir countries" of the Habsburg Empire. Among these instruments, the article aims to highlight the importance of culture and propaganda, which alongside politics and economics, allowed Italy to compete with the other great powers for hegemony in Central-Eastern Europe. The other nations'strategies will be taken into consideration as well in order to highlight in a comparative way the role that cultural and propaganda institutions played in the policies of the great powers during this important period of reconstruction.

A complex of Italian cultural activities and institutions focused on the study of Central and Eastern Europe, which had been established during the First World War and continued to operate in the post-war period at the time of the last liberal governments, was then strengthened by the fascist regime. Fascism made full use of the potential offered by cultural diplomacy to reinforce its positions in Central and Eastern Europe. Mussolini's unrealistic great power ambitions, however, eventually rendered the network of cultural institutions responsible for the study of Eastern Europe useless as they finally collapsed with the fall of his regime.
\end{abstract}

Keywords: Italy, Central-Eastern Europe, Culture, Propaganda, Fascism

DOI: https://doi.org/10.31577/forhist.2021.15.1.4

$\mathrm{D}$ uring the First World War, Italy laid the foundations of a strategy to be fully developed in the coming years of political penetration into Central-Eastern Europe, a plan in direct competition with the Entente's allied great powers, France and Great Britain. ${ }^{1}$ Like them, the Italian ruling class soon understood, as early as the war years, how cultural initiatives and propaganda were indispensable tools for complementing classic diplomacy in order to execute a policy of great power abroad. Italy then began to conceive of a scheme of establishing cultural institutions with the task of bolstering the image of Italy abroad, and starting collaborative relationships with the ruling classes of nations which were finally independent of the Habsburg Empire. During the last year of the war, the government's sensitivity around the topic of propaganda changed, with the turning point being the Italian defeat of Caporetto (Kobarid).

This essay develops, integrates and updates research undertaken by the author in previous works, among them the book SANTORO, Stefano. L'Italia e l'Europa orientale. Diplomazia culturale e propaganda 19181943. Milano : FrancoAngeli, 2005.

1 SANDERS, Michael L. - TAYLOR, Philip M. British Propaganda During the First World War, 1914-1918. London: The Macmillan Press, 1982; TAYLOR, Philip M. Propaganda in international politics 1919-1939. In SHORT, K. R. M. (ed.) Film \& Radio Propaganda in World War II. London; Canberra : Croom Helm, 1983; MESSINGER, Gary S. British propaganda and the state in the First World War. Manchester; New York : Manchester University Press, 1992. 
Between October and December 1917, following changes in the top ranks of the government and army, there was a transition to a modern vision of the war effort where the rigid, top-down and coercive element gave way to a more democratic and persuasive approach. The aim was to create a consensus and gain acceptance for the grandiose effort, in terms of men and means, necessary to launch a counter-offensive and achieve victory against the Austro-Hungarian Empire. For this purpose, a propaganda office active since 1916 was fortified and the publication of newspapers, leaflets and postcards started, aimed at reigniting the fighting spirit, hatred for the enemy and creating the atmosphere of a "sacred union" in defence of the homeland. Not only was propaganda directed towards the "internal front", i.e. the civilian population, and the troops, but also towards enemy armies in order to leverage the concept of nationality and to portray Italy as a friendly nation. This would allow for destruction of the "Habsburg oppressor" and liberation of the "oppressed peoples" from Austria. ${ }^{2}$

Of great importance at this time was the Congress of Oppressed Nationalities held in the capitol of Rome in April 1918. The idea of such a council had initially started with some well-known journalists, like director of the Corriere della Sera Luigi Albertini, writer Giuseppe A. Borgese and Giovanni Amendola, both collaborators of Albertini's newspaper, who wanted to bring together capital representatives of the national movements of the Austro-Hungarian Empire. Representatives of Central and Eastern European national movements attended the Congress of Rome (Romanian, Polish, Czechoslovak and Yugoslav delegations were present), who agreed to division of the Austro-Hungarian Empire according to nationality. Interventionist Italian politicians, both liberal-democratic and nationalist, joined with several parliamentarians, journalists and public figures belonging to the most diverse colour of irredentism, from Gaetano Salvemini to Benito Mussolini. Foreign Minister Sidney Sonnino proved to be sceptical, maintaining his anti-Yugoslav position and considering the Italian and Yugoslav claims on the Adriatic incompatible. Prime Minister Vittorio Emanuele Orlando demonstrated himself to be more accommodating for the moment, probably considering it useful at that stage not to hinder a policy of cooperation between Italy and the "oppressed nationalities" in respect to the war effort against the Empire. ${ }^{3}$

The Corriere della Sera celebrated the Congress, promoting Italy to the role of political and spiritual guide for the new nations that would achieve independence upon the dissolution of the Austro-Hungarian Empire. In the name of Mazzini's teaching: "The commonality of the supreme vital reasons holds together the oppressed peoples of Austria-Hungary in the great crusade. Yesterday the President of the Conference, in greeting the delegations who came to Rome before the end of the work, remembered a great name: that of Giuseppe Mazzini. He was the prophet of this crusade and of the concord celebrated in these days."

2 PISA, Beatrice. La propaganda e l'assistenza sul fronte interno. In LABANCA, Nicola (ed.) Dizionario storico della prima guerra mondiale. Roma; Bari : Laterza, 2014, pp. 218-229; CORNWALL, Mark. The Undermining of AustriaHungary. The Battle for Hearts and Minds. Basingstoke : Palgrave Macmillan, 2000.

3 CARTENY, Andrea. Il congresso di Roma, patto per le "nazionalità oppresse" dell'Austria-Ungheria (1918). In CARTENY, Andrea - PELAGGI, Stefano. Stato, Chiesa e Nazione in Italia. Contributi sul Risorgimento italiano. Roma : Edizioni Nuova Cultura, 2016, pp. 163-191; LEONCINI, Francesco (ed.) Il patto di Roma e la legione ceco-slovacca: tra Grande Guerra e nuova Europa. Vittorio Veneto : Kellermann, 2014.

4 G. A. [AMENDOLA, Giovanni]. Lalleanza fra i popoli pel riassetto civile del mondo. In Corriere della Sera, 12. April 1918, p. 2. 
Actually, the final resolutions of the Congress, which recognized "in the Austro-Hungarian Monarchy the instrument of Germanic domination and the fundamental obstacle to the realization of the [...] aspirations and [...] rights" of the peoples and "the need for a common struggle against common oppressors for each people to achieve total liberation and complete national unity in a free state unity", were extremely vague in regard to the question of the Adriatic lands. ${ }^{5}$ Yet despite these weaknesses, the Congress had an important promotional impact, placing Italy at the forefront of the movement of "oppressed peoples". It was in this context that the Czechoslovak legion was formed, made up of Czech and Slovak prisoners of war from the Austro-Hungarian army in Italian prison camps, and organized by Milan Rastislav Štefánik in the model of the Czechoslovak army constituted in France in December 1917. Shortly after, a Romanian legion was formed by Romanian Transylvanian professor Simion Mândrescu, president of the Society of Romanians from Transylvania, Banat and Bukovina. ${ }^{6}$ Similarly, from the spring of 1918 a Polish company was established and recognized as a military unit part of the French army fighting alongside the Italian army. ${ }^{7}$

\section{Competition Among Victorious Nations in the First Post-war Period}

At the end of the war, Central-Eastern Europe was completely transformed following the disappearance of the Habsburg, German and Russian Empires and, contrary to the expectations of the winning parties at the time of entering the war, new nations had arisen or had drastically reconfigured their boundaries over the entirety of that vast area. ${ }^{8}$ In the post-war period with the Peace Conference still underway, the winning powers had to face a threat brought by Russian Bolshevism and attempts to export the revolution to Central-Eastern Europe where from March to August 1919, a Soviet republic was established in Hungary on the Russian Leninist model..$^{9}$ It was mainly France that launched a dual intervention policy in Europe, on one hand aimed at preventing the re-establishment of German influence, and on the other hand to stem the "Bolshevik contagion" in Eastern Europe. ${ }^{10}$ France

5 Impegni solenni e fiere dichiarazioni a Roma nel Convegno delle Nazionalità oppresse dall'Austria. In Corriere della Sera, 11. April 1918, p. 1.

6 GRITTI, Fabiano. La fine della missione militare italiana in Cecoslovacchia nel 1919 alla luce dei documenti d'archivio italiani. In Studi italo-slovacchi, 2018, Vol. 7, No. 1, pp. 96-109; SALZANO, Mario Giulio. Il campo di concentramento per prigionieri di guerra di Fonte d'Amore e la formazione della Legione cecoslovacca (1916-1918). In Storia e problemi contemporanei, 2016, No. 71, pp. 139-160; NECHVATAL, Martin. La naissance d'une armée tchécoslovaque en France. In Guerres mondiales et conflits contemporains, 1993, No. 169, pp. 37-41; BRAUD, Emmanuelle. À l’origine de la création de l'armée tchécoslovaque en France: le général Milan Rastislav Štefánik. In Revue historique des armées, 2009, No. 255, pp. 79-83, http://journals.openedition.org/rha/6790; SANTORO, Stefano. I volontari romeni sul fronte italiano nella Prima Guerra Mondiale e la Legione romena d'Italia. In DINU, Rudolf - FIRŢA-MARIN, Aurora - LUCA, Cristian (eds.) La Campagna di Romania (1916-1917): esperienze e memoria storica. Atti del Convegno di studi italo-romeno. Venezia, 13-14 ottobre 2016. Quaderni della Casa Romena di Venezia, 2017, No. 12, Bucarest, 2017, pp. 149-162; CAPPELLANO, Filippo. La Legione Romena. In Studi storico-militari. 1996. Roma : Stato Maggiore dell'Esercito, Ufficio Storico, 1998, p. 227-247.

7 SONDEL-CEDARMAS, Joanna. I polacchi dell'Impero austro-ungarico e il fronte italiano nelle memorie dei legionari. In CIAMPANI, Andrea - SALWA, Piotr (eds.) La Grande Guerra e la Polonia in Europa. Atti del Convegno. Roma, 12-13 novembre 2015. Roma : Accademia Polacca delle Scienze Biblioteca e Centro di Studi a Roma, 2016, pp. $87-103$.

8 MACARTNEY, Carlile Aylmer - PALMER, Alan Warwick. Independent Eastern Europe. A History. London; New York : Macmillan, 1962.

9 LOMELLINI, Valentine (ed.) The Rise of Bolshevism and its Impact on the Interwar International Order. London : Palgrave Macmillan, 2020; FORNARO, Pasquale. Crisi postbellica e rivoluzione. L'Ungheria dei Consigli e l'Europa danubiana nel primo dopoguerra. Milano : FrancoAngeli, 1987; FORNARO, Pasquale. Una rivoluzione impossibile. Béla Kun e la Repubblica dei Consigli del marzo-agosto 1919. In BASCIANI, Alberto - RUSPANTI, Roberto. La fine della Grande Ungheria fra rivoluzione e reazione [1918-1920]. Trieste : Beit, 2010, pp. 71-96.

10 HOVI, Kalervo. Cordon Sanitaire or Barrière de l'Est? The Emergence of the New French Eastern European Alliance Policy 1917-1919. Turku : Turun Yliopisto, 1975; WANDYCZ, Piotr S. France and Her Eastern Allies 1919-1925. French-Czechoslovak-Polish Relations from the Paris Peace Conference to Locarno. Minneapolis : The University of 
was also flanking its continental strategy to reaffirm its role as a great power in post-war Central-Eastern Europe with a series of coordinated cultural initiatives, the crux of which was the Institut d'études slaves in Paris. At the same time, alongside the consolidated network of Alliance française units abroad active since the $1880 \mathrm{~s}^{11}$, a network of French cultural institutes, the Instituts français, began to be developed. In 1920, the French government decided to found the Service des œuvres françaises à l'étranger (SOFE), which within the Ministry of Foreign Affairs had the task of coordinating the actions of French cultural institutes abroad - and therefore, in particular, the Instituts français. ${ }^{12}$ Central-Eastern Europe was a privileged field for expansion also from a cultural point of view for France, which could benefit from a post-war German crisis and rely on the tight cultural relations that had been established with all those nations since the $19^{\text {th }}$ century. After the war, France could therefore continue to play the role of "cultural capital" of Eastern Europe, at a time in which political and cultural influence became complementary and constituted two instruments of a vast hegemonic design that would truly unfold in the interwar period. ${ }^{13}$

It follows that since the end of the war, an open rivalry between Italy and France - which England also joined - for hegemony in Central-Eastern Europe began. Of crucial importance for Italy: the question of the border with the new Kingdom of Serbs, Croats and Slovenes (Yugoslavia). ${ }^{14}$ It was the Giolitti government, with Foreign Minister Carlo Sfor$\mathrm{za}$, that made a change in relations with Yugoslavia. For the time being, the option of an Italian-led, anti-Yugoslav block was abandoned and Italy signed the Rapallo treaty with Yugoslavia on 12 November 1920, obtaining Istria up to Monte Nevoso (Snežnik), Zara (Zadar) and some islands. In return they officially recognized the new Yugoslav state. ${ }^{15}$ Sforza, an interventionist of Mazzinian ideals, was confident that Italy had the opportunity to take the place of the Habsburgs, but also of France in the Balkan balances and that to do this, it should carry out a policy of cooperation with the heir countries of the Habsburg Empire, starting with Czechoslovakia and Yugoslavia. In fact, an anti-Habsburg convention between Rome and Belgrade was added to the Rapallo treaty. Thereby Italy opened the way to the Sforza-Beneš note of 8 February 1921, with Czechoslovak accession to the anti-Habsburg convention of November 1920 and to the subsequent conference of the successor states of the Empire in Rome on 7 April 1921, which both the anti-revisionist countries as well as Austria and Hungary attended. More generally, Sforza's foreign policy

Minnesota Press, 1962; BONDARENKO, Dmytro. Poland, Romania, Finland: The formation of cordon sanitaire, 1918-1920. In Tyragetia, 2019, Vol. 13, No. 2, pp. 195-204.

11 BRUÉZIÊRE, Maurice. L'Alliance française. Histoire d'une institution. Paris : Hachette, 1983; CORTIER, Claude. Institution de l'Alliance française et émergence de la francophonie: politiques linguistiques et éducatives: 1880-1914. $\mathrm{PhD}$. thesis defended under the supervision of Norbert Dupont in 1998 at the University Lyon 2; CHAUBET, François. La politique culturelle française et la diplomatie de la langue. L'Alliance Française (1883-1940). Paris : L'Harmattan, 2006.

12 MARĖS, Antoine. Puissance et présence culturelle de la France. L’exemple du Service des Euvres françaises à l'Étranger dans les années 30. In Relations internationales, 1983, No. 33, pp. 66-67.

13 LOWCZYK, Olivier. La fabrique de la paix: du Comité d'Études à la conférence de la paix, l'élaboration par la France des traités de la première guerre mondiale. Paris : Economica, 2010, pp. 17-126; DELAPERRIERE, Maria - MARES, Antoine (eds.) Paris "capitale culturelle" de l'Europe centrale? Les échanges intellectuels entre la France et les pays de l'Europe médiane 1918-1939. Paris : Institut d'études slaves, 1997.

14 LE MOAL, Frédéric. La France et l'Italie dans les Balkans 1914-1919. Le contentieux adriatique. Paris : L'Harmattan, 2006; ALLAIN, J.C. La France et les Balkans pendant l'entre-deux guerres (1920-1938). In Relations Internationales, 2000, No. 103, pp. 351-359; CACCAMO, Francesco. L'Italia e la «Nuova Europa». Il confronto sull'Europa orientale alla conferenza di pace di Parigi (1919-1920). Milano; Trento : Luni Editrice, 2000, pp. 224-236, $282-293$.

15 LEDERER, Ivo J. La Jugoslavia dalla conferenza della pace al Trattato di Rapallo. Milano : Il Saggiatore, 1966, pp. 324-356. 
tended to impart a dynamic of cooperation between Italy and all the former Habsburg countries, including Poland and Romania. ${ }^{16}$

It was in those years that the Italian government led by Giovanni Giolitti deemed it appropriate to continue its work collaborating with the new ruling classes of the new nations. In particular, Italy looked at the heir countries of the Habsburg Empire, which due to their geographical proximity and traditional historical, economic and financial ties, constituted the preferred field for Italian expansion. They faced some formidable competition, however, especially from France but also from the other victorious powers like England and the United States, who also sought to strengthen their presence in the new nations. To this end, in addition to the usual political and economic penetration, each of these states began a new form of influence, experimented with during the war, which hinged on propaganda. In turn, in the first post-war period, a more refined form of propaganda was developed in an increasingly widespread manner, above all directed at the educated classes and the leadership circles. It was a more distinctly cultural propaganda, which took the form of a real cultural diplomacy. With this in mind, an institute was founded in Italy that would play a leading role in Italian cultural diplomacy. In January 1921, the Istituto per l'Europa Orientale, (IPEO, Institute for Eastern Europe), was born in Rome. The process that led to the creation of this institution shows the tight relationship between politics, diplomacy and culture during the first post-war period.

In effect, the initiative to found the Institute began with the head of the press office of the Ministry of Foreign Affairs, Amedeo Giannini, a scholar of international relations and in particular of the new Central-Eastern European nations. He took steps to ensure that Italy had organizations specialized in the study of Eastern Europe similarly to other European powers, believing that only a close collaboration between the political and cultural milieus would allow Italy to keep its channels of collaboration with the successors of the Habsburg Empire alive. ${ }^{17}$ The Foreign Minister Sforza, an assertor of decisive change of the Italian line in its relations with the former Habsburg nations, supported this initiative which he believed could bolster his policy of cooperation with the heir states on the cultural side. Moreover, Giannini included the main exponents of the nascent Italian Slavistics. It was this convergence between the interests of diplomacy and the interests of culture and politics that led to the establishment of the Istituto per l'Europa Orientale. ${ }^{18}$

16 MELCHIONNI, Maria Grazia. La politica estera di Carlo Sforza nel 1920-21. In Rivista di studi politici internazionali, 1969, Vol. 36, No. 4, pp. 558-570; MELCHIONNI, Maria Grazia. La convenzione antiasburgica del 12 novembre 1920. In Storia e politica, 1972, Vol. 11, No. 2-3, pp. 224-264, 374-417; BROGI, Alessandro. Il trattato di Rapallo del 1920 e la politica danubiano-balcanica di Carlo Sforza. In Storia delle relazioni internazionali, 1989 , No. 1, pp. 3-46; BRACCO, Barbara. Carlo Sforza e la questione adriatica. Politica estera e opinione pubblica nell'ultimo governo Giolitti. Milano : Unicopli, 1998; MONZALI, Luciano. La politica estera italiana nel primo dopoguerra 1918-1922. Sfide e problemi. In Italia contemporanea, 2009, No. 256-257, pp. 397-399.

17 SANTORO, Stefano. La diplomazia italiana di fronte allepurazione. Il caso di Amedeo Giannini. In Italia contemporanea, 1999, No. 216, pp. 529-540; MONZALI, Luciano. Amedeo Giannini e la nascita della storia delle relazioni internazionali in Italia. In Storia contemporanea, 1994, Vol. 25, No. 4, pp. 493-525.

18 Archivio Storico del Ministero degli Affari Esteri (ASMAE), Rome, fond Ministero della Cultura Popolare, b. 304, f. Istituto per l'Europa Orientale, 1921-24, Statuto dell'Istituto per l'Europa Orientale; SANTORO, Stefano. Cultura e propaganda nell'Italia fascista: l'Istituto per l'Europa Orientale. In Passato e presente, 1999, Vol. 17, No. 48, pp. 55-78; MAZZITELLI, Gabriele. Il fondo Ipeo nella biblioteca dell'Istituto di Filologia Slava dell'Università "La Sapienza" di Roma. In Slavia, 1994, Vol. 3, No. 4, pp. 181-213; MAZZITELLI, Gabriele. Le pubblicazioni dell'Istituto per l'Europa orientale. Catalogo storico (1921-1944). Firenze : Firenze University Press, 2016, pp. 27-56. 


\section{Cultural Institutions as a Complement to Political and Economic Penetration}

An additional component of Italian cultural diplomacy taking shape then was a network of cultural institutes that gradually took hold in Central and Eastern Europe, and served as a framework for the successful cultural penetration effort of Italy between the two World Wars. The institutes were initially called "Institutes of Italian Culture", but the names were changed in the mid-1930s, redefining themselves as "Italian Institutes of Culture" - this slight alteration being evidence of the fascist desire to underline the Italian core of these institutes. They served as outposts of Italy in the countries where they operated, becoming "cultural ambassadors" for the homeland. Initially, the Institutes sprang up spontaneously thanks to autonomous initiatives by Italians connected to academic circles abroad, and supported in turn by Italian diplomatic authorities - and by the Foreign Ministry - who viewed the increased cultural commitment of Italy with a positive eye.

The first Institute of Italian Culture in the former Habsburg area - and, apparently, the first ever $^{19}$ - was founded in Prague in October 1922 after several months of preparation. It was the result of a policy of opening up to the heirs of the Habsburg Empire desired by Foreign Minister Sforza. ${ }^{20}$ From a financial point of view, Italian banks and insurance companies immediately seized new opportunities offered by the new markets, resuming a penetration policy that had already begun at the beginning of the century. After WWI, Italy's economic strategy progressing eastward experienced a revival, always benefiting from the support of the major Italian banks. From Comit to Credito Italiano, to Banca Italiana di Sconto, they were ready to finance, in particular, the opportunities that opened up to some Italian business groups regarding the exploitation of raw material. Besides banks, insurance and shipping companies such as Assicurazioni Generali, Riunione Adriatica di Sicurtà (RAS) and Lloyd Triestino, were opening new branches throughout the former Habsburg area. ${ }^{21}$

In the immediate post-war period, Czechoslovakia played a strategic role for Italian trade, especially the port of Trieste. At the Peace Conference, Tomás Garrigue Masaryk had confirmed that the Czechoslovak delegation would not contest the "Italian-ness" of Trieste and Pola (Pula), while the Czechoslovak minister of Foreign Affairs, Edvard Beneš, had expressed to Sonnino the hope that Trieste would continue to be as in the past: "the southern outlet of Czechoslovak trade." ${ }^{22}$ M. R. Štefánik played an equally important role in regard to the establishment of closer economic and commercial relations between Italy and Czechoslovakia in those same years until his death. ${ }^{23}$ However, from the first

19 VIDOSSI, Giuseppe. "Necrologi”: Bindo Chiurlo. In Giornale Storico della Letteratura Italiana, 1944, Vol. 122, No. 364, p. 107.

20 SANTORO, Stefano. L'Italia e l'Europa orientale. Diplomazia culturale e propaganda 1918-1943. Milano : FrancoAngeli, 2005, p. 88.

21 WEBSTER, Richard A. Una speranza rinviata. Lespansione industriale italiana e il problema del petrolio dopo la Prima guerra mondiale. In Storia contemporanea, 1980, Vol. 11, No. 2, pp. 219-281; DI QUIRICO, Roberto. Il sistema Comit. Le partecipazioni estere della Banca commerciale italiana tra il 1918 e il 1931. In Rivista di storia economica, 1995, No. 2, pp. 175-217; DI QUIRICO, Roberto. Le banche italiane all'estero 1900-1950. Espansione bancaria all'estero e integrazione internazionale dell'Italia negli anni tra le due guerre. Firenze : European Press Academic Publishing, 2000; COSTANTINI, Emanuela - RASPADORI, Paolo (eds.) Prove di imperialismo. Espansionismo economico italiano oltre l'Adriatico a cavallo della Grande guerra. In Quaderni monografici di "Proposte e ricerche", No. 41, Macerata : Eum, 2017; STANCIU, Laura. Italian multinational banking in interwar east central Europe. In Financial History Review, 2000, Vol. 7, pp. 45-66; IACOPINI, Alessandro. Lespansione della Banca Commerciale Italiana in Europa orientale durante il fascismo. In Diacronie, 2013, Vol. 3, No. 15, https://doi. org/10.4000/diacronie.528.

22 BOLECH CECCHI, Donatella. Alle origini di un'inimicizia. Italia-Cecoslovacchia 1918-1922. Soveria Mannelli : Rubbettino, 2008, pp. 65-66.

23 CACCAMO, Francesco. L'ultima missione di Milan Rastislav Štefánik alla luce delle nuove fonti. In CAPUZZO, 
post-war period, the French presence in Czechoslovakia was instantly considerable and well regarded by the government of Prague. In fact, France was the only great power capable of guaranteeing the territorial integrity of the country and preventing a Habsburg revival in Hungary. At the same time, bilateral Italian-Czechoslovak relations went through a cooling period due to the growing closeness between Czechoslovakia and Yugoslavia in the name of common Slavic heritage, plus Prague's overall solidarity with Belgrade on the Adriatic problem. ${ }^{24}$

In this setting, the French position was much more condescending towards Czechoslovak requests and as such, increasingly bolstered at the expense of the Italians. This led to positive outcomes for Paris in the industrial and commercial fields. In addition, France made massive use of culture to support its penetration policy in Czechoslovakia and throughout former Habsburg Europe by sharply coordinating the activities of its Instituts français. The Institut français of Prague, founded in 1920 thanks to the contributions of the famous linguist Antoine Meillet, did not come to be accidentally in the capital of a country which was the cornerstone of the Little Entente: an anti-revisionist alliance comprised of Romania, Yugoslavia and Czechoslovakia and supported by Paris through a system of alliances with the contracting countries. ${ }^{25}$ The Institut français in Prague had experienced success with the Czechoslovak people from the outset and counted numerous members. It offered free French courses, created scholarships for Czechoslovak students in France, set up libraries and organized conferences. For its endeavours, the French Legation was provided with adequate funds to support the cultural activities of the Institute and the diplomatic staff was supported by an academic scholar whose specific task was developing cultural activities. ${ }^{26}$

The new plenipotentiary minister of Italy in Prague, Antonio Chiaromonte Bordonaro, who in October 1919 replaced chargé d'affaires Mario Lago, aware of the difficult Italian situation as compared to France had strengthened the Italian press agency in Prague and established an information service between the two capitals. During Sforza's tenure as Foreign Minister, Italy intensified its initiative in order to contend France's positions, taking advantage of the opportunity provided by the Czech-Polish rivalry for the Teschen area and therefore also the French difficulties in creating an anti-communist alliance with both countries - and rapprochement between France and Hungary, which was frowned upon by Prague, naturally. The possibility of resuming dialogue with the Slavic countries seemed to reappear, ideally similar to the experience of the Pact of Rome. ${ }^{27}$

The notion of establishing an Italian Institute of Culture in Prague met the favour of Amedeo Giannini and could count on the support of the exponents of Italian culture residing in the Czechoslovak capital, including the renowned writer from Trieste, Giani Stuparich, and the Friulian scholar Bindo Chiurlo, both lecturers at the Charles Universi-

Ester - CREVATO-SELVAGGI, Bruno - GUIDA, Francesco (eds.) Per Rita Tolomeo, scritti di amici sulla Dalmazia e l'Europa centro-orientale II. Venezia : La musa talia, 2014, pp. 208-228; KŠIŇAN, Michal. L'Homme qui parlait avec les étoiles. Milan Rastislav Štefánik, héros franco-slovaque de la Grande Guerre. Paris : Eur' ORBEM, 2019.

24 PERMAN, Dagmar. The Shaping of the Czechoslovak State. Diplomatic History of the Boundaries of Czechoslovakia 1914-1920. Leiden : Brill, 1962, pp. 18-25.

25 WANDYCZ 1962; IORDACHE, Nicolae. La Petite Entente et l'Europe. Genève : Institut Universitaire de Hautes Études Internationales, 1977.

26 CHEVALIER, Jean-Claude. Diffusion du français en Europe de l'est: 1920-1939. In KOK ESCALLE, Marie-Christine - MELKA, Francine (eds.) Changements politiques et statut des langues. Histoire et épistémologie 1780-1945. Amsterdam; Atlanta, GA : Editions Rodopi B.V., 2001, p. 137.

27 BOLECH CECCHI 2008; CACCAMO 2000, pp. 89-100; PERMAN 1962, pp. 228-233. 
ty of Prague. On the other hand, awareness that culture was an important tool on which to focus was also shared by the Italian finance world in Czechoslovakia. The local branches of Assicurazioni Generali and RAS contributed to the development of the Institute, as well as the shipping company Lloyd Triestino. From an ideal point of view, the Institute was born based on the Italian-Czechoslovak friendship which was strengthened during the last phases of the war in the common struggle against the Habsburg Empire; ideal references to the Czechoslovak legion in Italy were constant. In spite of anti-Slavic positions shown by Italian nationalism, this strand of Italian-Czechoslovak friendship had prevailed within interventionist circles. ${ }^{28}$ The policy of collaboration between the two countries - and more generally with the heirs of the Habsburg Empire - also continued at the beginning of Mussolini's government. At first, it brought forward Sforza's policy thanks to the influence of the Secretary General of the Foreign Ministry Salvatore Contarini, who was linked to Sforza and continuator of his anti-Habsburg cooperation policy. ${ }^{29}$

It was in this context that Mussolini surprisingly pursued Sforza's idea of collaborating with the Slavs. In January 1924, the Treaty of Rome was signed in which Italy and Yugoslavia committed themselves to supporting an anti-revisionist policy, defending the status quo produced by the treaties of Saint-Germain, Trianon and Neuilly. In exchange, Italy could obtain the city of Fiume (Rijeka). ${ }^{30}$ The Italian-Czechoslovak anti-revisionist collaboration agreement of July 1924 marked a continuation of this policy, and at the same time encapsulated the moment of the greatest proximity of fascist Italy to the Little Entente, whose foreign ministers delighted in the signing of this treaty. ${ }^{31}$ The Italian minister in Prague reported: "Benes [Beneš] informed the allies of the conclusion of the pact of cordial collaboration with Italy. Foreign ministers welcomed this by noting that this agreement lays on the line of conduct of the Little Entente and Duca [the Romanian Foreign Minister] declared in this regard that economic divergences with Italy will soon be settled." ${ }^{32}$ However, the Italian-Czechoslovak friendship treaty did not seem to bear fruit from the beginning, which was also due to strained relations between Mussolini and Beneš. In any case, the Italian-Romanian treaty of friendship of 1926, which was part of Mussolini's attempt to form a "Danubian-Balkan Locarno", could therefore still be included in this context, whereby Italy as a great power would have to guarantee the stability of the countries of that area. Romania was probably the one country of the Little Entente that had better relations with Italy and less prejudice against the fascist regime, and whose support it needed to obtain Italian recognition of the annexation of Bessarabia at the end of the war. From that moment on, however, the policy of collaboration with the heirs of the Habsburg Empire went into crisis from the end of the 1920s, and Mussolini decidedly took the path of support for revisionist requests present in Central-Eastern Europe. ${ }^{33}$ The general change in

28 SANTORO 2005, pp. 81-88.

29 CAROCCI, Giampiero. La politica estera dell'Italia fascista (1925-1928). Bari : Laterza, 1969, pp. 18-31; ANASTASI, Matteo. Salvatore Contarini e la politica estera italiana (1891-1926). Roma : Aracne, 2017.

30 BUCARELLI, Massimo. Mussolini e la Jugoslavia (1922-1939). Bari : Edizioni B.A. Graphis, 2006, pp. 27-34.

31 Documenti. Pacte de collaboration cordiale entre le Royaume d'Italie et la République Tchécoslovaque. In L'Europa Orientale, 1924, Vol. 4, No. 8-11, p. 589.

32 Documenti Diplomatici Italiani (DDI), Series 7, Vol. 3, No. 387, The minister in Prague, Pignatti, to the president of the Council and minister of Foreign Affairs, Mussolini, T. 4394/274, Prague, 14. July 1924.

33 RICCARDI, Luca. Il trattato italo-romeno del 16 settembre 1926. In Storia delle relazioni internazionali, 1987, Vol. 3, No. 1, pp. 39-72; CASSELS, Alan. Mussolini's Early Diplomacy. Princeton, NJ : Princeton University Press, 1970, pp. 175-184; CAROLI, Giuliano. La Romania nella politica estera italiana 1919-1965. Luci e ombre di unamicizia storica. Milano : Edizioni Nagard, 2009, pp. 99-110; CACCAMO, Francesco. Italia e Cecoslovacchia negli anni Venti. In Nuova storia contemporanea, 2000, No. 2, pp. 59-76; BURGWYN, H. James. Il revisionismo fascista. 
Italian foreign policy towards the Balkans was greatly influenced by the reigniting of the Italian-Yugoslav rivalry over control of Albania, which between 1926 and 1927 became increasingly closely linked to Rome at a time when the removal of Contarini from his position as Secretary General of the Ministry of Foreign Affairs in 1926 and the arrival of Dino Grandi led to a further fascistization of the Ministry and also caused the definitive abandonment of cooperation with the heir states and the start of the revisionist option. ${ }^{34}$

\section{Culture as an Instrument of Fascist Italy's Great Power Ambitions}

The ties of anti-Habsburg collaboration between Italy and the Central-Eastern European national movements in the last phase of the war, which climaxed with the "brotherhood of arms" of the legions, had provided the ideal driving force around which Italian political and cultural penetration initially developed in the former Habsburg area. It is therefore no coincidence that the only other properly titled "Institute of Italian Culture" in Central-Eastern and Danubian-Balkan Europe until the mid-1930s was, in addition to that in Prague, in Bucharest. It was founded in the early 1920s with a similar dynamic: the support of the Italian political and business world was superimposed on an initiative launched by advocates of culture. ${ }^{35}$ Relations with both countries proved difficult in the following years as mutual interests conflicted. With Romania however, the myth of "Latinity" which Italian cultural diplomacy was articulated and implemented around, allowed Italy to maintain a solid presence - at least from a cultural point of view - despite everything else that was happening. ${ }^{36}$

Regarding Yugoslavia, although political relations had improved in 1924 for a short period of time, cultural relations were never particularly easy either, having to face decades of Italian-Slav conflict starting from the end of the $19^{\text {th }}$ century. ${ }^{37}$ Until the mid-1930s, Yugoslavia was subject to the destructive attention of Italian publications, emphasizing Italian rights in Dalmatia and condemning Serbian centralizing policy towards the Slavic Catholics, Slovenians and Croats. Despite this, a considerable part of the Italian diplomatic personnel - for example the Italian ambassador in Belgrade in the early 1930s, Carlo Galli, and Dino Grandi, Italian Foreign Minister from 1929 to 1932 - was more willing to reach an agreement with Belgrade, considered convenient to Italy, and similar ideas were shared in parts of the Italian north-eastern business world. ${ }^{38}$ It was in the second half of the 1930s that, especially with Milan Stojadinović coming to power, being the latter well disposed towards Mussolini, relations between the two countries improved. Following the Italian-

La sfida di Mussolini alle grandi potenze nei Balcani e sul Danubio 1925-1933. Milano : Feltrinelli, 1979; COLLOTTI, Enzo. Fascismo e politica di potenza. Politica estera 1922-1939 (with the collaboration of Nicola Labanca and Teodoro Sala). Milano : La Nuova Italia, 2000, pp. 37-38.

34 BORGOGNI, Massimo. Tra continuità e incertezza. Italia e Albania (1914-1939). La strategia politico-militare dell'Italia in Albania fino all'Operazione "Oltre Mare Tirana". Milano : FrancoAngeli, 2007, pp. 86-99.

35 SANTORO 2005, pp. 114-115.

36 SANTORO, Stefano. L'Italia e la Romania fra diplomazia e cultura, 1918-1943. In Romanian Review of Political Sciences and International Relations, 2004, Vol. 1, No. 2, pp. 61-95.

37 CATTARUZZA, Marina (ed.) Nazionalismi di frontiera: identità contrapposte sull'Adriatico nord-orientale 18501950. Soveria Mannelli : Rubbettino, 2003; KIRCHNER REILL, Dominique. Nationalists Who Feared the Nation: Adriatic Multi-nationalism in Habsburg Dalmatia, Trieste and Venice. Stanford : Stanford University Press, 2012; CATTARUZZA, Marina. L'Italia e il confine orientale. Bologna : il Mulino, 2007; MONZALI, Luciano. Italiani di Dalmazia 1914-1924. Firenze : Le Lettere, 2007, pp. 1-24.

38 MONZALI, Luciano. La Jugoslavia e l'assetto dell'Europa centrale nella politica estera dell'Italia fascista (19221939). In GUIOTTO, Maddalena - WOHNOUT, Helmut (eds.) Italien und Österreich im Mitteleuropa der Zwischenkriegszeit / Italia e Austria nella Mitteleuropa tra le due guerre mondiali. Wien; Köln; Weimar : Böhlau Verlag, 2017, pp. 158-159. 
Yugoslav friendship treaty of March $1937^{39}$, the two countries also signed a cultural agreement, which provided for the creation of an Institute of Italian Culture in Belgrade. It was established in October 1939 and inaugurated in February 1940. Subsequently, in April 1940 an institute of culture was opened in Ljubljana, while another was present in Zagreb since February. In particular, the institutions of Zagreb and especially Ljubljana carried out the crucial task of pushing Italian propaganda towards the Slavic element after the occupation of Yugoslavia by Axis forces and the creation of the "province of Ljubljana" in April-May $1941 .^{40}$

From the second half of the 1930s, Italian cultural diplomacy was put at the service of the revisionist policy of fascist Italy in Central-Eastern Europe, oriented in an anti-Yugoslav sense, and supported the clerical-fascist and nationalist movements in Austria, Hungary, Croatia and Bulgaria in order to weaken the Yugoslav kingdom. Anti-Habsburg solidarity had now given way to the myth of Latinity and Rome as the sentinel of civilization against the assaults of Asian Bolshevism. ${ }^{41}$ In terms of propaganda and cultural penetration, the slow decline of French influence, begun well before June 1940, had given way to a new formidable rival of fascist Italy: the Third Reich. Nazi propaganda showed great organization immediately and could count on huge state funding as well as on large German Volksdeutsche communities scattered in all the former Habsburg countries. ${ }^{42}$ To respond to the intense competition exercised by Nazism among the so-called moderate bourgeoisies and rightwing nationalist and radical circles, Mussolini decided to strengthen the Italian cultural institutes, centralizing their organization with an office created ad hoc at the Ministry of Foreign Affairs. In actuality, the function of the Italian cultural institutes had already been regulated in 1926, especially concerning the foundation rules of these institutions which otherwise risked developing in an impromptu and uncoordinated way, essentially by individual initiatives as happened for the Institutes of Italian culture in Prague and Bucharest in the early 1920s. ${ }^{43}$ Under the direction of Galeazzo Ciano, the Ministry of Foreign Affairs decidedly focused on the Institutes of Italian Culture in the former Habsburg territories, increasing their funding and issuing guidelines in the second half of the 1930s explicitly recommending underlining the primacy of Italy as a dispenser of civilization among the peoples of Eastern Europe. In the mid-1930s, Institutes of Italian Culture were established in all capital cities of the countries of Central and Eastern Europe, with a network of affiliates operating in provincial towns. Moreover, in the second half of that decade, through a growing centralization of cultural and propaganda activities abroad, Italy aimed to stem German propaganda, asking the Institutes to underline the spiritual superiority of Christian Italy towards "Teutonic racist paganism".

39 BUCARELLI, Massimo. Gli accordi Ciano-Stojadinović del 25 marzo 1937. In Clio, 2000, Vol. 36, No. 2, pp. $327-$ 395.

40 SANTORO, Stefano. La diplomazia culturale italiana in Jugoslavia durante il fascismo. In Annales. Anali za istrske in mediteranske študije. Series Historia et Sociologia, 2003, Vol. 13, No. 1, pp. 125-148.

41 SANTORO, Stefano. The Latin "Frontier of Civilization": Italian Cultural Policies and Fascist Propaganda Towards Central and Eastern Europe in the Interwar Period. In MOGA, Valer - ARHIRE, Sorin (eds.) Frontierele Europei Central-Estice între geografia politică şi mitologia națională (secolele XIX-XX). Annales Universitatis Apulensis. Series Historica, 2015, Vol. 19, No. 1, pp. 155-168.

42 LUMANS, Valdis O. Himmler's Auxiliaries. The Volksdeutsche Mittelstelle and the German National Minorities of Europe, 1933-1945. Chapel Hill; London : The University of North Carolina Press, 1993; KOMJATHY, Anthony Tihamer - STOCKWELL, Rebecca. German Minorities and the Third Reich. Ethnic Germans of East Central Europe between the Wars. New York; London : Holmes \& Meier Publishers, 1980.

43 FOSCHI, Franco. Sugli Istituti italiani di cultura allestero. Note e riflessioni. Firenze : Vallecchi, 1980; BAISTROCCHI, Massimo. Elementi di politica culturale estera. Roma : Armando, 1985; CAVAROCCHI, Francesca. Avanguardie dello spirito. Il fascismo e la propaganda culturale allestero. Roma : Carocci, 2010. 
The Institute of Italian Culture in Vienna played a strategically important role here in the time of rapprochement between fascist Italy, Austria, and Hungary formalized through the Rome protocols of March 1934. In this way, Mussolini planned to contain German expansionism towards Danubian-Balkan Europe and especially towards Austria. ${ }^{44}$ Even in this case, the means offered by culture flanked traditional diplomacy. In February 1935, Italy signed cultural agreements with Austria and Hungary that would lead to the founding of Italian cultural institutes in Vienna and Budapest. Direction of the Institute in Vienna was entrusted to the Istrian historian Francesco Salata, plenipotentiary minister in the Austrian capital in 1936-1937 and a deep connoisseur of the Austrian world. He was on good terms with Austrian Chancellor Schuschnigg - who took over for Dollfuss in July 1934 after his assassination at the hands of the Nazis - and a staunch supporter of Austrian independence. The Institute then carried out the important function of guarding the Italian presence in Austria and Central Europe. Following the Italian-German rapprochement resulting from the Ethiopian war and the international sanctions to which Italy was subjected, Italy's role in Austria declined and the Institute charted a similar descending parable, underlined by the dismissal of Salata. ${ }^{45}$

\section{The Crisis of Mussolini's Hegemonic Project in Central-Eastern Europe}

Italy therefore had to gradually give up its political-economic expansion towards DanubianBalkan Europe, preferring to concentrate on the Mediterranean and colonial sector. This was due also to the consequences of the economic crisis that had affected the entire area in the early 1930s. The Italian financial and commercial retreat, in fact, gave way to powerful German economic penetration ${ }^{46}$, however, it is significant that this did not entail cultural abandonment for Italy, which was an attempt to counter the creation of a new German-led central Europe, at least on a propaganda level. In order to support these pursuits, which increasingly took on political flavour with conferences on the achievements of fascism (corporatism, land reclamation, "battle of wheat", policies in favour of birth), other institutions were deployed such as the CAUR (Action Committees for the Universality of Rome), which aimed to unify intellectuals and politicians of the European right around the myth of Latinity played in an anti-Nazi key.

This was the golden age of "fascist international", which in the name of a frequently unclear pan-fascist ideology and of the myth of the "Third Rome" aimed to confederate all European fascist and corporate movements as well as parties under the direction of Italian fascism. ${ }^{47}$ At the heart of this strategy was still the use of Italian culture and history for

44 PETERSEN, Jens. Hitler e Mussolini. La difficile alleanza. Roma; Bari : Laterza, 1975, pp. 291-297; BURGWYN, H. James. La troika danubiana di Mussolini: Italia, Austria e Ungheria, 1927-1936. In Storia contemporanea, 1990, Vol. 21, No. 4, pp. 617-686; RÉTI, György. Hungarian-Italian Relations in the Shadow of Hitler's Germany, 19331940. New York : Columbia University Press, 2003.

45 RICCARDI, Luca. Per una biografia di Francesco Salata. In Clio, 1991, Vol. 27, No. 4, pp. 660-664; RICCARDI, Luca. Le carte Salata: quarant’anni tra politica e storia. In Quaderni giuliani di storia, 1991, Vol. 12, No. 1-2, pp. 80-81, 90-91; RICCARDI, Luca. Francesco Salata tra storia, politica e diplomazia. Udine : Del Bianco, 2001.

46 BEREND, Iván T. - RÁNKI, György. Lo sviluppo economico nell'Europa centro-orientale nel XIX e XX secolo. Bologna : il Mulino, 1978, pp. 287-337; GRENZEBACH, William S. Jr. Germany's Informal Empire in East-Central Europe: German Economic Policy toward Yugoslavia and Rumania, 1933-1939. Stuttgart : Franz Steiner Verlag, 1988; KAISER David E. Economic Diplomacy and the Origins of the Second World War. Germany, Britain, France and Eastern Europe 1930-1939. Princeton : Princeton University Press, 1980; OVERY, Richard J. Business in the Grossraumwirtschaft: Eastern Europe, 1938-1945. In JAMES, Harold - TANNER, Jakob (eds.) Enterprise in the Period of Fascism in Europe. London; New York : Routledge, 2017, pp. 151-177.

47 CUZZI, Marco. L'internazionale delle camicie nere. I CAUR, Comitati d'azione per l'universalità di Roma 1933-1939. Milano : Mursia, 2005; LEDEEN, Michael Arthur. L'internazionale fascista. Roma; Bari : Laterza, 1973; LONGO, 
propaganda purposes, for example through the recovery of the Mazzinian myth representing Italy as a spiritual guide for nations of the former Habsburg Europe. As previously mentioned, this myth was at the centre of the first post-war initiatives and remained the ideal point of reference for many intellectuals operating in Italian cultural institutes. It is interesting that one of those institutes, founded in 1937 by the publicist Pietro Gorgolini, was called Istituto Europa Giovane and evidently still referred to Giuseppe Mazzini with its name. Adhering to the Institute of Fascist culture, this establishment referred to corporatism and opposed communism and "Asiatism", while its program aimed to "reinvigorate in the intellectuals the awareness of the great Western civilization, essentially Greek-Roman, Catholic, Fascist".48

Between the end of the 1930s and the war years, Italian cultural institutes in the former Habsburg space, and more broadly in Central-Eastern Europe, came to be on the front line and were increasingly involved in the war effort. German authorities often saw the Italian institutes as dangerous competitors for propaganda and attempted to limit their activity. In October 1938, Ettore Lo Gatto, Slavist and professor of Italian literature at Charles University of Prague since 1936, was appointed director of the Institute of Italian Culture in Prague. Lo Gatto, who enjoyed undoubted esteem in local intellectual circles - and who was the first Slavist to direct the Institute - managed to relaunch the institute, though he soon found himself in a very difficult phase after the dissolution of Czechoslovakia. In particular, after the establishment of the Protectorate of Bohemia and Moravia, German authorities showed a growing diffidence towards the activities of the Institute, which appeared to be enjoying great success, and also of Lo Gatto himself, perceived as a natural "friend" of the Slavs, whereby the German authorities let the Italians know that they would prefer a "non-Slavist" as director. Lo Gatto returned to Rome in October 1941, officially for health reasons but probably also because the Italian diplomatic authorities of the protectorate wanted to avoid friction with the Germans, and was replaced by an Italianist. ${ }^{49}$

This "surrender" of Italian cultural diplomacy to the Germans in Prague can be considered paradigmatic of the overall exhaustion with the experience of cultural penetration of fascist Italy in the former Habsburg territories. Whilst the appeal of alma mater Rome and of the myth of Latinity in Central-Eastern Europe had undoubtedly allowed Italy to win the sympathies of a part of the local educated and bourgeois classes, overall, Italian cultural diplomacy showed its objective limits compared to the much more aggressive German propaganda machine, which could rely on the impressive economic and military resources of Third Reich.

In the early second post-war years, Italy would attempt to continue its presence in Central and Eastern Europe, also through cultural institutions even within a radically changed political framework, reopening numerous Institutes of Italian Culture between 1947 and

Gisella (ed.) I tentativi per la costituzione di un'internazionale fascista. Gli incontri di Amsterdam e di Montreux attraverso i verbali delle riunioni. In Storia contemporanea, 1996, Vol. 27, No. 3, pp. 475-567; BLINKHORN, Martin. Fascism and the Right in Europe 1919-1945. New York : Routledge, 2013.

48 Archivio Centrale dello Stato, Rome, fond Ministero della Cultura Popolare, Gabinetto, b. 74, f. 494, Istituto "Europa Giovane", Istituto scientifico-letterario Europa Giovane aderente all'Istituto nazionale di cultura fascista del P.N.F. Programma attività adesioni 1937-38-39, supplement No. 3 of Nazionale.

49 SANTORO 2005, pp. 390-394; MAZZITELLI 2016, pp. 220-221; GHETTI, Maria Cecilia. La cattedra padovana di Filologia Slava: i primi cinquant'anni (1920-1970). In MINGATI, Adalgisa - CAVAION, Danilo - CRIVELLER, Claudia (eds.) Uomini, opere e idee tra Occidente europeo e mondo slavo. Scritti offerti a Marialuisa Ferrazzi. Trento : Università degli Studi di Trento, 2011, pp. 292-293. 
1948. However, it was clear that the rhetoric of Latinity, which had been the basis of Italian cultural activities, would find a great obstacle in the Soviet presence leveraging the theme of pan-Slavism and aiming to Slavicize - culturally speaking - even non-Slavic nations like Romania. It was also clear that after WWII, Italy would no longer be in a position to pursue a policy of great power in general, and even less towards Central and Eastern Europe. From the main target of Italian expansionist policies in the interwar period, former Habsburg Europe became an almost marginal and forgotten area by both the Italian ruling classes and public opinion, while all attention was focused on the birth of the new bipolar equilibrium. ${ }^{50}$ According to available documentation, by 1948 in Central-Eastern Europe, Italian cultural institutes continued to operate in Czechoslovakia, Hungary and Romania, while the Institute of Vienna was being reconstituted. Furthermore, regarding Italian chairs and language classes in foreign universities and schools between 1947 and 1948, they were working, albeit in small proportions, in Poland, Czechoslovakia, Hungary and Romania. ${ }^{51}$

Despite the Italian will to keep these cultural institutions alive, the beginning of the cold war and especially the outbreak of the Korean war in 1950 saw a hardening by the USSR and satellite countries towards the presence of western cultural institutes, and consequently of Italian institutions, which were forced to close. ${ }^{52}$ Only the Italian Institute of Culture in Budapest was allowed to continue, while the others were only reopened starting from the 1960s with the beginning of the détente between East and West. ${ }^{53}$

50 VIGEZZI, Brunello. De Gasperi, Sforza, la diplomazia italiana e la politica di potenza dal trattato di pace al patto atlantico. In DI NOLFO, Ennio - RAINERO, Romain H. - VIGEZZI, Brunello. L'Italia e la politica di potenza in Europa (1945-50). Milano : Marzorati, 1990, pp. 3-6; BIANCHINI, Stefano. Lopinione pubblica e l'immagine dell'Europa danubiano-balcanica: dalla fine del conflitto alla guerra fredda. In DI NOLFO, Ennio - RAINERO, Romain H. - VIGEZZI, Brunello. L'Italia e la politica di potenza in Europa (1945-50). Milano : Marzorati, 1990, pp. 447-449.

51 BRUSASCA, Giuseppe (ed.) Il Ministero degli Affari Esteri. Al servizio del popolo italiano (1943-1949). Roma : Tipografia riservata del Ministero degli affari esteri, 1949, pp. 154-155.

52 GORI, Umberto. La “diplomazia” culturale multilaterale dell'Italia. Elementi per uno studio sistematico dell'azione italiana nel quadro di una teoria delle relazioni internazionali. Roma : Bizzarri, 1970, p. 58, footnote 56.

53 MEDICI, Lorenzo. Dalla propaganda alla cooperazione. La diplomazia culturale italiana nel secondo dopoguerra (1944-1950). Milano : Cedam, 2009, pp. 144, 165-168.

\footnotetext{
Cite: DOI: https://doi.org/10.31577/forhist.2021.15.1.4

Stefano Santoro

Università degli Studi di Trieste

Dipartimento di Studi Umanistici

Androna Campo Marzio 10, 34123 Trieste, Italy

email: ssantoro@units.it
}

SANTORO, Stefano. Italy's Great Power Strategies in Central-Eastern Europe Between the World Wars: Cultural Institutions and Political Propaganda. In Forum Historiae, 2021, Vol. 15, No. 1, pp. 35-47. ISSN 1337-6861. 